\title{
Co-management in mangrove rehabilitation at langkat regency
}

\author{
A.Hadian Pratama Hamzah ${ }^{1 *}$, Sutrisno Anggoro², and Sri Puryono ${ }^{3}$ \\ ${ }^{1}$ Doctoral Program of Environmental Science, School of Postgraduate, Universitas Diponegoro, \\ Indonesia \\ ${ }^{2}$ Water Resources Management, Faculty Leaders of Fisheries and Marine Science, Universitas \\ Diponegoro, Indonesia \\ ${ }^{3}$ Postgraduate Program Enviromental Science, Universitas Diponegoro, Indonesia
}

\begin{abstract}
Collaboration in the management of mangrove areas is a role for every social element in an area government, community, and private parties. Co-management is an alternative solution in the form of management that integrates the roles and interests of everyone in the mangrove rehabilitation program. This study aims to analyze the role and level of influence of the interests of each actor in mangrove rehabilitation activities in Langkat Regency. The research method uses descriptivequalitative, data collected from the results of questionnaires, interviews; field observations are processed in the form described in the description on the tabulation. From the results of this study, the form of co-management in mangrove rehabilitation is at a consultative stage where the government begins to consider local views in the decision-making process, the level of participation of each stakeholder in the low category, so this study recommends that the form of participation of each stakeholder can be increased through the form of regulations together, a program of sustainability and systematic distribution of work that is socialized to every implementer of the mangrove rehabilitation program in Langkat District. ${ }^{*}$
\end{abstract}

\section{Introduction}

Humans and the environment have a very close relationship, where humans take the results of the environment and the environment is the life cycle of civilization [1]. The utilization of natural resources obtained from the environment is natural, such as water, air, heat, and waves generated by currents. The current coastal conditions are areas that are very vulnerable to environmental changes and close to damage. Human activities that move from urban to rural areas are also one of the issues that can no longer be avoided, some people choose to do vacation activities in urban areas while others choose to find a place to relax in the mountains and coastal areas, where the attractions offered by the manager are part of the activities refreshment and vacation.

\footnotetext{
*Corresponding author: hadi.dian@yahoo.com
} 
The phenomenon of coastal areas that now range from environmental changes ranging from housing development, places of entrepreneurship such as fish and shrimp cultivation as well as tourist attractions that require land clearing in coastal areas are now rife in the world, including Indonesia. In 2017 the issue of reclamation of the Jakarta bay beach is widely discussed as evidence of environmental management that is not environmentally friendly and supports environmental sustainability.

Where the coastal area which is ideal as a buffer against tidal waves going to the mainland is now being built into an apartment area, mall, and also recreation facilities in the coastal area [2]. The change of an area into various designations is influenced by various factors, including factors such as the level of income, political interests, and the public's perspective on the use of an area. Most cases that occur at this time are economic and political interests that make an area turn into another designation by being used without regard to the environmental carrying capacity and carrying capacity of an area is holding the burden of activities that occur in that region [3]. The variety of human activities in an area also takes a role in the occurrence of a change in regional conditions.

Currently, the coastal area is experiencing a change in circumstances where cases occur such as Bangladesh and Thailand where the destruction of a coastal buffer zone, namely mangrove forests, is also a cause of disasters on the coast, this is caused by the loss of green lines or mangrove buffer areas and changing coastlines due to the conversion of mangrove land. The worst condition due to damage to the mangrove forest area is the sinking of an island in Langkat Regency, namely in the old Tapak Kuda Village.

Due to the intrusion of seawater which eventually submerged the island and there was a new area called the New Horse Tread. This condition stems from the loss of mangrove hectares due to conversion into shrimp and milkfish ponds as well as the Wampu river development project which turtles pay attention to environmental feasibility aspects in implementing the project [4]. Coastal areas in Langkat Regency are also in the spotlight today where mangrove damage and forms of rehabilitation have been carried out for the past ten years [5]. The form of participation of each stakeholder in post-rehabilitation conservation activities still needs to be identified, so the purpose of this study is designed to identify the form of co-management carried out by interested parties in the management of mangrove areas in Langkat Regency. This study was designed to analyze the form of importance and the level of influence of each actor in mangrove management. Phenomenon analysis is carried out using an environmental approach and policy perspective.

\section{Research Method}

The method in this study uses descriptive qualitative where the phenomenon of comanagement in mangrove conservation in Langkat District was collected with primary data through questionnaires, in-depth interviews with parties involved in mangrove conservation activities and observations in the mangrove forest area of Langkat District conducted during the research activities, as for things that were observed include the profile of Langkat Regency, the form of mangrove area utilization and the condition of mangrove environment stability in Langkat Regency.

Secondary data as support in the analysis of this study were taken from journals, books, previous research and writing in online media, the presentation of research data is displayed in the form of narrative and qualitative data in the form of tabulations, percentages, and graphs to strengthen the comprehensive findings in this study. 


\section{Result and Discussion}

\subsection{Langkat Regency Profile}

Langkat Regency is known as a coastal area which is rich in marine and forest resources. Langkat also has social and cultural potential with a very high historical value as a coastal tourism destination [6]. Langkat Regency has an area of $\pm 6,263.29 \mathrm{Km} 2(626,329 \mathrm{Ha})$ consisting of 23 Districts and 240 Villages and 37 Definitive. Potential jobs in Langkat Regency include fishermen, micro and small businesses, agriculture, forest product processing, tourism, sea product processing, and government workers. From 1,041,775 residents of the regency of 560,645 residents who live in the coastal areas, including as fishermen, processing sea products, processing of coconut, breadfruit, palm oil, and working as a port worker who lifts goods from the ship's cargo [6]. Two potential commodities in Langkat Regency are sea products and tourism, this is because Langkat is a coastal area that sells the beauty of the sea and protected forest areas for nature tourism activities. For almost 200 years, Langkat people have replaced their livelihoods from marine products and tourism. Langkat Regency has a long history of sultanate forms in government so that many architectures and historical relics are often visited by local and foreign tourists as research or historical tourism. From abundant sea products and good soil fertility in Langkat District, around 30\% of the community's condition is in the category of underprivileged families, where income levels, education levels, and access to employment opportunities are low [7].

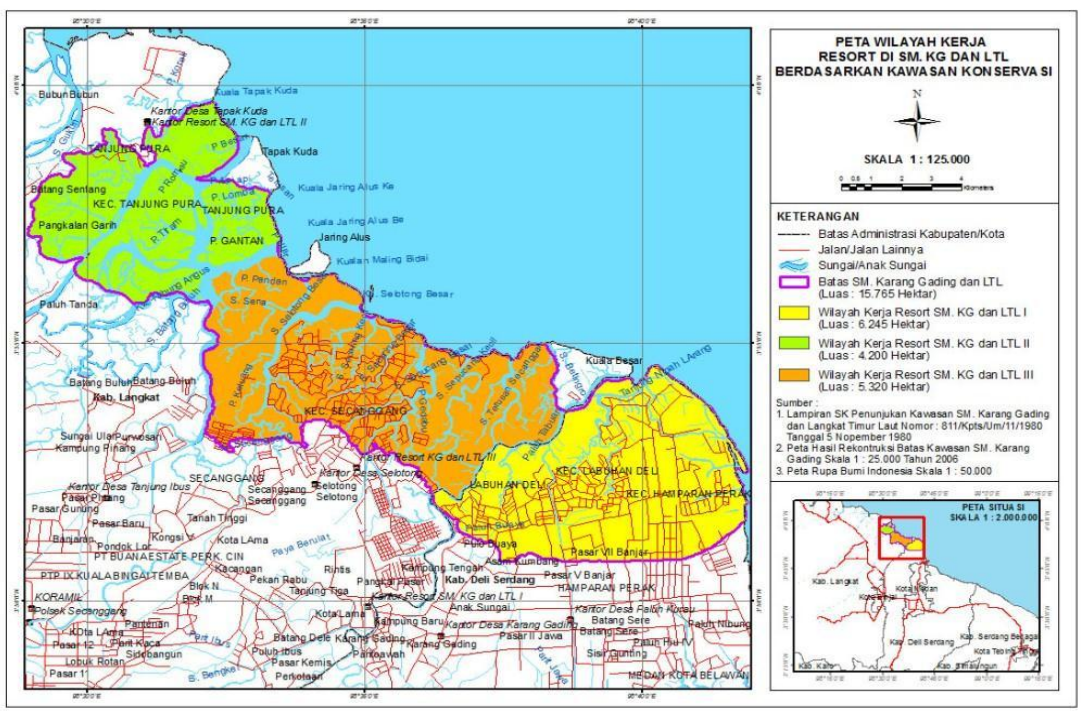

Fig. 1. Distribution of Mangrove Forests in Langkat Regency

Various forms of utilization of natural resources from marine and forest products make the community have a high level of dependence on the availability of natural products both marine and forest products which also contribute the greatest contribution to local income. The current environmental problem in Langkat Regency is the destruction of the mangrove forest area which is found in nine sub-districts which are the place for the community's livelihood, the distribution of mangrove forests can be seen in Figure 1. 
With a high level of dependence on marine products, the existence of mangrove forests directly impacts the availability of fish, crabs, squid, and other mangrove forest ecosystem service conditions for coastal communities [8]. The function of mangrove forests as nested fish areas can reduce the number of fish and other waters if the ecological function of mangrove forests is disrupted [8]. This condition ultimately impacts on people who are looking for livelihoods from marine products as well as environmental conditions that are threatened by disasters if mangrove forests are damaged or extinct [9].

\subsection{Mangrove Condition in Langkat Regency}

There are 9 districts with the distribution of mangrove areas in Langkat Regency, namely in the districts of Tanjung Pura, Sei Lapan, Pematang Jaya, Secangang, Pangkalan Susu, West Brandan, Gebang Besitang Babalan. [10]. There were total differences in the size of 1989 and 2010, the total area of sub district mangrove forests is shown in table 2.

Table 1. Mangrove forest area of Langkat

\begin{tabular}{|c|c|c|c|c|c|c|}
\hline & $\begin{array}{c}\text { Area of } \\
\mathbf{1 9 7 7}\end{array}$ & & $\begin{array}{c}\text { Area of } \\
\mathbf{2 0 0 6}\end{array}$ & & Change & \\
\hline Kecamatan & Ha & $\mathbf{\%}$ & Ha & $\mathbf{\%}$ & Ha & \% \\
\hline Babalan & $2.318,64$ & 6,18 & 140,47 & 1,20 & $2.178,16$ & 93,94 \\
\hline Besitang & $2.803,88$ & 7,47 & 407,55 & 3,48 & $2.396,32$ & 85,46 \\
\hline Br. Barat & $3.274,40$ & 8,73 & $1.070,38$ & 9,14 & $2.204,02$ & 67,31 \\
\hline Gebang & $4.483,76$ & 11,95 & $1.057,42$ & 9,03 & $3.426,34$ & 76,42 \\
\hline Pkl. Susu & $5.674,14$ & 15,12 & $1.723,13$ & 14,72 & $3.951,01$ & 69,63 \\
\hline Pmt Jaya & 479,37 & 12,20 & $2.440,80$ & 20,85 & $2.138,57$ & 46,70 \\
\hline Secanggang & $6.457,95$ & 17,21 & $2.459,07$ & 21,00 & $3.998,88$ & 61,92 \\
\hline Sei Lapang & 71,04 & 0,19 & 19,82 & 0,17 & 51,22 & 72,10 \\
\hline Tj. Pura & $7.862,21$ & 20,95 & $2.390,51$ & 20,42 & $5.471,49$ & 69,59 \\
\hline Total & $37.525,17$ & 100 & $11.709,16$ & 100 & $25.816,01$ & 68,80 \\
\hline
\end{tabular}

Based on a description of the ever-decreasing extent of mangrove forests in Langkat District, in 2011 the Langkat Regency government through regional government regulation number 14 of 2011 concerning the Spatial Planning for the Langkat District 2011-2031 stipulated one of the targets in the field of environmental management in the forest rehabilitation program mangrove in Langkat Regency.

Damage to mangrove areas on the coast of Langkat Regency has changed the socioeconomic and environmental conditions in Langkat, the amount of economic income and the forms of livelihoods of residents in coastal areas have also changed [11]. The livelihoods of coastal communities are dominated by work as fishermen and the small business and tourism sector [12]. The level of damage to mangrove forests at $68 \%$ which occurred in almost nine districts in Langkat Regency needs to be rehabilitated.

In 2011 the local government through the Forestry Service issued a mangrove rehabilitation program in a coastal area that suffered damage to mangrove forests. Of the nine sub districts that became the point of the rehabilitation program in 2016, there were only two sub-districts that successfully managed to rehabilitate, namely Secanggang subdistrict with increasing cover by $60 \%$ to 3,934.16 Ha and West Brandan District which increased $80 \%$ to $1,920 \mathrm{Ha}$ from the conditions before mangrove rehabilitation [5]. this condition affects the return of the coastal environment in the two sub-districts, the thing that is considered significant is the fishermen's income from fishing and the level of production of processed marine products is easier to obtain and there is no scarcity in obtaining them 
such as shrimp as material for making shrimp paste and mangrove crabs for commodities sold to markets other than fish.

Changes in the condition of mangrove density also contribute to the beauty and beauty of the environment where ecotourism activities in the Lubuk Kertang mangrove areas of West Brandan and West Brandan sub-districts reopened in 2017 after nearly 5 years ago the beauty of the mangrove forests could no longer be enjoyed [13]. Of the seven sub-districts that have not shown significant results, the average level of area change is only $10-30 \%$, which means that it has not reached $50 \%$ of the process of progress in land cover change after the loss of mangrove area in each district. from the change in the condition of mangrove forests, it is necessary to have a study on joint management or co-management of areas that have increased changes in the condition of mangrove forests before rehabilitation and after rehabilitation activities, this will be an overview as well as findings that these factors are some determinant in the success of a rehabilitation program in an area.

\subsection{Co-management of Mangrove Rehabilitation in Langkat}

The role of the government, the community, and the private sector is a deciding factor in the success of a program, most studies show that partial participation, namely the role of government that is not supported by the community will not succeed, the role of the community that is maximized without government assistance will not run optimally, forms of financial assistance provided by companies in the form of corporate social responsibility as well as most studies show that the company will only carry out funding and the name of the program but the sustainability of a program that lacks assistance will not last long, this is the case for mangrove rehabilitation studies in Asia [14].

Various roles in a rehabilitation program are important, through the work of each stakeholder the purpose of the activity is directed and the achievement of results is easy to evaluate its implementation. The mangrove rehabilitation program in Langkat District has been carried out through a co-management approach, this is demonstrated through the collaboration of stakeholders in the formulation of programs and evaluations that are jointly planned. As for the results of the measurement of the level of importance and the level of influence in the mangrove rehabilitation program measured through the theory of interest analysis and the level of importance [15]. The results of this study revealed that the role in the interests of management and the level of stakeholder interests in mangrove rehabilitation in Langkat Regency is illustrated in Figure 2.

Identification related to the mangrove rehabilitation program in Langkat District, there were fifteen stakeholders, namely mangrove farmer groups, fishermen groups, farmers, Regency Governments, Maritime and Fisheries Service, Forest Service, Environmental Service, Watershed Management Agency, Police / Kodim, LSM, academics, crab seekers, oyster seekers, firewood seekers, building wood users and surrounding communities. 


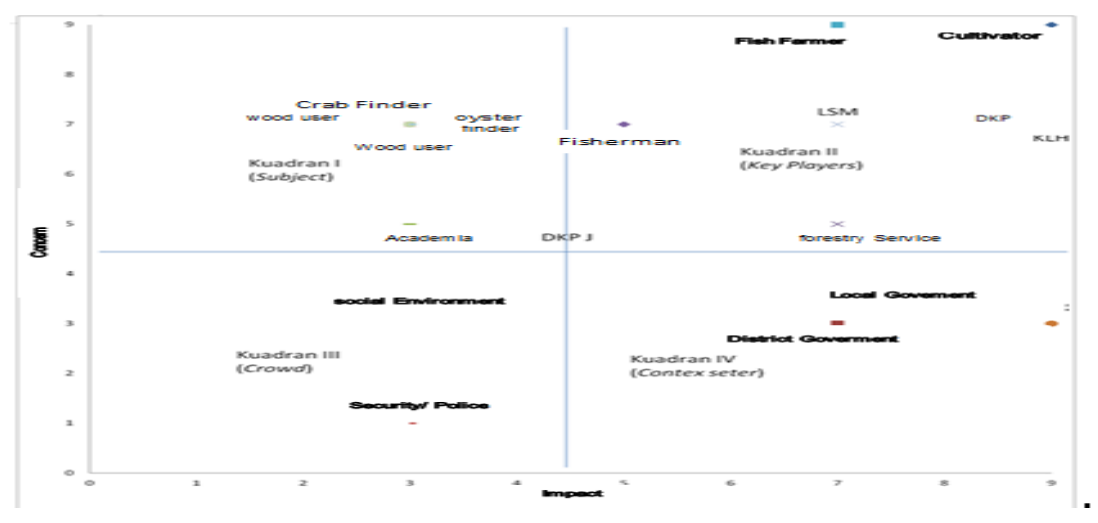

Fig. 2. Stakeholder Interest Level

Based on the spectrum of co-management compiled by Adrianto (2009) in the mangrove rehabilitation program in Langkat Regency, it is at the consultative stage. In terms of conditions, at this stage, the government has conducted discussions and dialogues with stakeholders in the mangrove rehabilitation program in Langkat. However, in the formulation of activity plans, the organization, supervision, and evaluation of each stakeholder is limited to the government, structurally it is not comprehensive for all stakeholders in the mangrove rehabilitation program. The tendency in the implementation of the program is still running independently and lack of collaboration between interested agencies and with other stakeholders. Information exchange is still one-sided because communication and coordination between the government and other stakeholders are still lacking.

In this case, the work process of mangrove rehabilitation in Langkat is carried out in the division of labor without coordinated communication between stakeholders. In this case, the lines of communication between each stakeholder need to be carried out systematically and in a scheduled manner. Many program failures are not in the form of activities but communication patterns between each program implementer that are not yet clear and get feedback [16]. In the implementation of mangrove rehabilitation in Langkat District, new co-management was carried out in the form of formalization in which the implementation manuals contained in the program implementation practices were compiled systematically, but the implementation had not yet reached the understanding of each party involved in implementing the program under the guidelines due to lack of socialization, counseling and mentoring at the time of program implementation [17].

Community participation as program implementers needs to be monitored in the implementation process, this is because the level of education, length of stay, type of work, and gender contribute to the factor of community participation in a regional program [18]. Many cases in various countries explain their findings that co-management is one way to solve a social problem by involving many parties, but in some countries such as India and Brazil, the form of a rehabilitation activity is centered on the community, this is because a system monitoring carried out by the government about a program has been determined by default and the government as a decision-maker recognizes the characteristics of the area it leads, when a region has a good level of participation, the form of the delegation that can be done in a program.

Finally, the form of co-management is implemented as a solution to social phenomena in an area, the effectiveness of a form of collaboration between stakeholders is based on three things namely time effectiveness, resource effectiveness, and financial effectiveness in implementing programs. Co-management that is carried out must have short, medium, and long-term goals because a rehabilitation program needs to encourage the form of 
sustainability in a program that is carried out. As an example of the success of the West Brandan District in mangrove rehabilitation due to community involvement and local initiative factors in the implementation of the program [19], most of the areas in Langkat District are still waiting for a mentoring role in program implementation efforts, this can be caused by factors of education, level of knowledge and gender in implementing the program. The level of importance and the influence of interests are also factors in the success of a program, the government runs the program as an output of the performance products of regional managers, the community as an element of an area needs to be involved because the socio-economic sustainability of the community depends on conducive environmental conditions, as implementing business processes in the region a lot depends on the existence of the environment, so the role of companies in environmental management also needs to continue to be involved.

\section{Conclusion}

Co-management carried out in the mangrove rehabilitation program in Langkat Regency is carried out through the involvement of the government as a decision-maker, the community as the program implementer, and the private sector as assistance and funding in rehabilitation activities. Currently, only $30 \%$ of each sub-district has advanced in improving conditions, there are only two sub-districts that have succeeded in rehabilitation activities namely West Brandan and Secangang. Encouragement of participation of each stakeholder needs to be done in the form of the formation of an independent management body, the form of a joint working group, and the establishment of regulations. 


\section{References}

1. A. Huff, E.S.R.C, 1 (2017)

2. R. Puspasari, S. T. Hartati, and R. F. Anggawangsa, J. Kebijak. Perikan. Ind. 9, 85 (2018)

3. D. J. Prihadi, I. R. Riyantini, and M. R. Ismail, J. Kelaut. Nas. 1 (2018)

4. A. H. Pratama, B. Gunawan, and B. Cahya, J. Ilm. Peuradeun, 4, 357 (2016)

5. M. Basyuni, Y. Bimantara, B. Selamet, and A. Siddik Thoha, Abdimas Talent 1, 31 (2016)

6. BPS, “Kabupaten Langkat Dalam Angka, 2020,” ( 2020)

7. H. G. Desi Novita, J Grium 21, 49 (2017)

8. A. Muqarrobin, F. Yulianda, and T. Kodiran, Bonoworo Wetl. 3, 114 (2013)

9. I. E. Bayan, F. Yulianda, and I. Setyobudiandi, Bonorowo Wetl 6, 1 (2016)

10. Onriza, Jur. Bio. 6, 163 (2010)

11. Rudianto, J. Perikan. UGM, 20, 1 (2018)

12. R. Hafni, Jurn. Eko. K 16, 1 (2016)

13. D. A. Friess et al., Conserv. Bio. 30, 933 (2016)

14. Adrianto, Indinator Keberhasilan pendekatan ekosistem dalam pengelolaan perikanan dengan Ko-management. (2007)

15. L. L. Chinangwa, A. S. Pullin, and N. Hockley, J. Sust. For. 36, 338 (2017)

16. N. C. Duke, Tropical forestry handbook (Trop. For. Handb. 2014)

17. R. DasGupta and R. Shaw, Participatory mangrove management in a changing climate: perspectives from the asia-pacific (Handbook, 2017)

18. R. Borges, A. C. Ferreira, and L. D. Lacerda, Front. Mar. Sci. 4, 1 (2017)

19. R. Adenan, Adv. Soc. Sci. Res. J. 5, 27 (2018) 